Matej NIKŠIČ

Alenka FIKFAK

Christine MADY

\title{
Editorial Changing streets in changing cities: Providing streets for all?
}

City streets are the most enduring urban components accompanying changes through time. They are mirrors of cities' histories and everyday social practices. Streets are mnemonic spaces (Hebbert, 2005), capturing the interaction between space, people, and social practices, and accompanying and imprinting our everyday lives (de Certeau, 1998). They are the type of public open spaces that have been studied from various perspectives, including their cultural, social, economic, and legal dimensions (Vernez Moudon, 1991; Fyfe, 1998; Loukaitou-Sideris \& Ehrenfeucht, 2009). However, although streets have been a common topic of research and implemented projects across the globe and across disciplines, their socio-spatial complexities call for on-going and continuous endeavours towards their further exploration (Sharifi, 2019; Bertolini, 2020).

In light of present-day challenges affecting cities, there is a rising concern about transformations streets must undergo in order to address new realities and needs. This special issue proposes to address the following questions: Which conceptual frameworks are useful to examine the relationship between city streets and other urban systems that constitute the city? What are the methodological challenges of studying urban streets as an explanatory framework of urban phenomena? What are the rules of the game and who are the main players in shaping contemporary streets? How are behaviours, needs, and aspirations of the contemporary street users reflected in streetscapes? Which are the tendencies and drivers of change that may influence the conceptual and practical approaches to street (re)design in the near and distant futures?

The idea for this special issue stems from the international interdisciplinary virtual conference City Street " ${ }^{4}$ "Streets for 2030: Proposing streets for integrated and universal mobility" (Fikfak et al., 2020), held in Ljubljana and specifically focused on transformations for universal mobility as understood in the broader term of the mobility turn (Urry \& Sheller, 2006), and in relation to the UN-Habitat SDGs for 2030. This fourth conference in the series of City Street conferences offered a rich overview of scholarly and practical work in the field and provided a platform for discussions on the roles and issues that streets and their makers as well as users have been recently facing. The aim of this special issue is to provide the basis for further reflections, research, and discussions on the selected themes.

The seven contributions in the special issue respond to one or more of the posed questions. Their topics range from accessibility and mobility, public spaces within housing projects, methodologies of studying public space transformations and walkability, and the environmental performance of pedestrian zones. Marchigiani et al. address spatial accessibility as a right and catalyst for urban inclusion. Accessibility allows for active living and participation in urban life. The paper investigates the locations of public spaces, their role in active living, and the 
role of accessibility in urban regeneration. In a broader sense, it touches upon mobility and social justice, wellbeing, and the role of public spaces. Two papers shed light on informal mobility in Beirut, Lebanon. In the first, Mady provides an overview of the public transportation system in Beirut, the challenges it has faced under perpetual political instabilities, and the consequent birth of the informal bus system. It focuses on understanding the impact of spatial divides on people's mobility patterns and experiences, hence reflecting embedded conditions affecting everyday mobility in Beirut. The second paper, a case study using the lens of participatory research, charts the development of the Beirut grassroots initiative (later NGO) "Bus Map Project" / "Riders' Rights" and its fight for spatial justice in the context of allpervasive consociational "democracy". The paper by Petrovič Krajnik et al. aims to demonstrate how the spatial, morphological, and functional transformation of public space contributes to the aspects of sustainability in relation to traffic, landscape, facilities, and urban equipment issues, and thus positively impacts wellbeing. The two-level methodology considers the urban structure within the wider spatial context first and then focuses on the selected public area in the city centre. Žnidaršič and Juvančič explore walkability issues through the multidimensionality approach. The overarching walkability themes derive from research and theoretical contributions of various authors and are structured into operational walkability principles. These are developed further into implementable interventions and items with the focus on residential environments. Tasheva-Petrova et al. present the case-study of Sofia in order to illustrate the complexity of interests and interactions in the public space of prefabricated housing estates inherited from the socialist period. The capacity of the planning system to address them, and the rationale and limitations of participatory planning approaches in conceptualizing conflicts and providing solutions, is discussed, offering a concept of "public" life and space in contemporary urban development of Modernist heritage. Finally, Martínez Mansilla examines the environmental performance of pedestrian zones in Tarija, Bolivia, with the purpose of enhancing urban social life by improved accessibility and increased mobility under specific climatic conditions. The proposed scheme with simulation modelling could provide a template for implementation in other urban places all over the globe.

In line with the goals of Urbani izziv, this issue as a whole aspires to open and address the relevant and meaningful questions of the past, present, and future of streets in order to contribute to the establishment of the conceptual frameworks and methodological approaches to the challenges ahead of us. As the cases presented in the authors' contributions illustrate, streets in diverse spatial and social contexts face different challenges and require tailored approaches. At the same time, certain common challenges can be identified, such as the role of streets regarding growing social disparities, environmental issues, new technology-driven developments, etc. We wish you an enjoyable reading and a fruitful reflection!

\section{Matej Nikšič, Urban Planning Institute of the Republic of Slovenia, Ljubljana, Slovenia (matej.niksic@uirs.si)}

Alenka Fikfak, Department of Urban Planning, University of Ljubljana, Ljubljana, Slovenia (alenka.fikfak@fa.uni-lj.si)

Christine Mady, Department of Architecture, Notre Dame University-Louaize, Zouk Mosbeh, Lebanon (christine.mady@ndu.edu.lb)

\section{Acknowledgments}

The co-editors would like to thank the Urbani Izziv editor Damjana Gantar for her constant guidance and support throughout the preparation of this special issue. The editorial team acknowledges financial support from the Slovenian Research Agency (research core funding No. P5-0100). 


\section{References}

Bertolini, L. (2020) From "streets for traffic" to "streets for people": Can street experiments transform urban mobility? Transport Reviews, 40(6), pp. 734-753. DOI: 10.1080/01441647.2020.1761907

de Certeau, M. (1988) The practice of everyday life. Berkeley, University of California Press.

Fyfe, N. R. (ed.) (1998) Images of the street: Planning, identity and control in public space. London, New York, Routledge.

Fikfak, A., Nikšič, M., Mady, C., Bizjak, I. \& Blenkuš, M. (eds.) (2020) City Street ${ }^{4}$ Conference. Streets for 2030: Proposing streets for integrated and universal mobility, 23-26 September. Ljubljana, University of Ljubljana, Faculty of Architecture, Urban Planning Institute of the Republic of Slovenia.

Hebbert, M. (2005) The street as locus of collective memory. Environment and Planning D: Society and Space, 23(4), pp. 581-596. DOI: 10.1068/d55j

Loukaitou-Sideris, A. \& Ehrenfeucht, R. (2009) Sidewalks: Conflict and negotiation over public space. Cambridge, MA, MIT Press. DOI: 10.7551/mitpress/7423.001.0001

Sharifi, A. (2019) Resilient urban forms: A review of literature on streets and street networks. Building and Environment, 147, pp. 171-187. DOI: 10.1016/j.buildenv.2018.09.040

Urry, J. \& Sheller, M. (2006) The new mobilities paradigm. Environment and Planning A: Economy and Space, 38(2), pp. 207-226. DOI: 10.1068/a37268

Vernez Moudon, A. (ed.) (1991) Public streets for public use. New York, Columbia University Press. 